\title{
Chapter
}

\section{Impacts of e-wastes on water resources and their management}

\author{
Syed Rouhullah Ali* and Mahrukh \\ College of Agricultural Engineering and Technology, Sher-e-Kashmir University of \\ Agricultural Sciences and Technology of Kashmir 190025, J\&K, India
}

\begin{abstract}
Waste electrical and electronic equipment (WEEE) or e-waste refers to obsolete, unwanted Electrical/Electronic devices that have reached end of life. Broadly, e-waste consists of plastics, glass, printed circuit boards, ceramics, rubber, ferrous and non-ferrous metals, elements like lead, mercury, cadmium, silver, gold, platinum etc. Owing to the lack of sufficient facilities for the safe management of waste in developing countries, this waste is buried, burned in the open air or dumped into surface water bodies. e-waste disposal in landfills and incinerators does permanent damage to the atmosphere by water and soil pollution and air contamination. In sediments of water bodies near e-waste disposal sites, heavy metals (e.g., lead, cadmium, copper and zinc) and organic pollutants (e.g., PCDD / Fs and PBDEs) were found in quantities that greatly exceed the background levels. The aquatic organisms that live in the affected water bodies are highly exposed to these toxic, bio-accumulative, and persistent contaminants. This study presents an overview of toxic substances present in e-waste, their potential impact on water bodies and human health together with its management.
\end{abstract}

Keywords e-waste, Electrical and electronic equipment, Heavy metals, Human health 


\section{Introduction}

The rapid pace of urbanisation is a challenge to urban environmental management in most developing countries. Industrial revolution accompanied over the last century by developments in information technology has dramatically altered the lifestyle of the people. Electronic waste (e-waste) is one of the main waste management issues facing some urban areas. e-wastes consist of the disposal of electronic devices such as computers, telephones and mobiles. The increasingly rapid evolution of electronic technology combined with rapid obsolescence of the product has compounded the issue of e-waste (Otsuka et al., 2012). Much of electrical and electronic equipment (EEE) has a short lifespan and fast turnover. Frequently, obsolete or damaged EEE is not recycled or repaired, but, more likely, is simply thrown away. Thus, the amount of waste electrical and electronic equipment (WEEE), such as superseded personal computers, mobile phones, entertainment equipment, and electronic consumer equipment has proliferated immensely during the last decades. e-wastes are considered harmful, since certain components of some electronic devices contain hazardous materials, depending on their condition and density. Some highly toxic elements, such as chlorinated and brominated compounds, toxic gases, radioactive metals, biologically active materials, acids, plastics and chemical additives, are found in personal computers (PCs). The dangerous material of these items poses a threat to the environment and health. (Jain, 2009).

Today, the production of electrical and electronic device waste is the fastest growing waste source worldwide about $4 \%$ growth each year and accounts for up to $8 \%$ of all urban waste (Streicher-Porte $e t$ al., 2005). Globally produced e-waste is rising at a rate nearly three times faster than total solid municipal waste (Schluep et al., 2009). The global e-waste generation by various devices is shown in Figure 1.

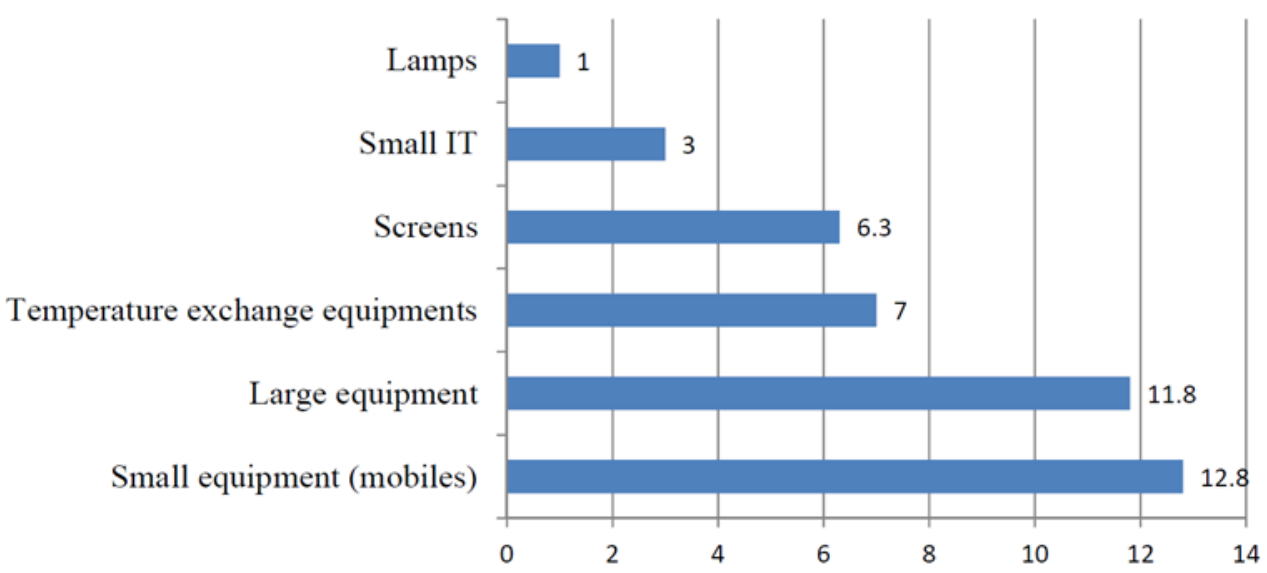

Figure 1. Global e-waste generation by different equipment

(Source: Garg and Adhana, 2019) 


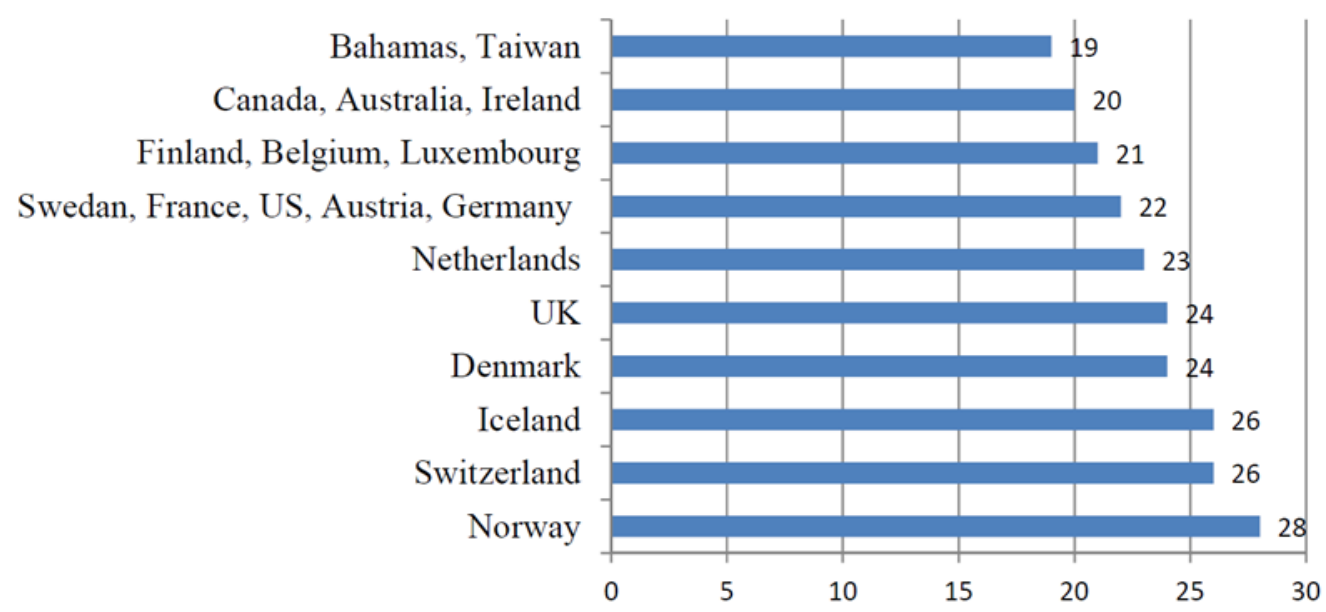

Figure 2. Highest e-waste generating countries (Source: Garg and Adhana, 2019)

The rapid obsolescence of many electronic products is triggered by the continuous introduction of new designs, smart functions and technology over the last 20 years. The service life of many electronic products has been reduced considerably due to advances in electronics, enticing consumer designs and marketing and compatibility problems. For example, a new computer's average lifespan has declined from 4.5 years in 1992 to an estimated 2 years in 2005 and is declining further (Widmer et al., 2005) resulting in much higher volumes of computers for disposal or export to developing countries. The big issue with e-waste in developing countries stems from the importation of e-waste and electronic products from developed countries because it is the older, less eco friendly equipment that is discarded from these Western countries that exports 80 percent of all e-waste in developed countries (Hicks et al., 2005). According to UNEP (2010), the annual e-waste generated worldwide is estimated to be 20-50 million tons $(\mathrm{t})$. between $50 \%$ and $80 \%$ of such e-waste is prospectively exported to developing countries like Ghana, China, India and Nigeria (Puckett and Smith, 2002; UNEP, 2005; Frazzoli and Orisakwe, 2010; Environmental Investigation Agency, 2011; Lundstedt, 2011). In a survey, the Basel Action Network (BAN) reported that $50 \%-80 \%$ of e-waste collected by the United States is exported to India , China, Pakistan, Taiwan and a number of African countries (Puckett et al., 2002). The largest e-waste producing countries are described in Figure 2. Few protections, legislation, policies and regulation of the safe disposal of imported e-waste and electronic products in those countries have caused significant human and environmental problems.

Electronic products frequently contain many persistent, bioaccumulative and toxic substances like heavy metals such as lead, nickel, chromium and mercury, as well as persistent organic contaminants (POPs), such as polychlorinated biphenyls (PCBs) and brominated flame retardants. In e-waste, the 
proportion of iron, copper, aluminium, gold and other metals is over $60 \%$, while plastics account for about $30 \%$ and dangerous contaminants account for just about 2.70\%. (Widmer et al., 2005). The Basel Action Network (BAN) reports that the world's 500 million computers produce 2,87 billion $\mathrm{kg}$ of plastics, 716,7 million $\mathrm{kg}$ of lead and $286,700 \mathrm{~kg}$ of mercury, respectively. The typical 14 -inch monitor uses a tube which is estimated to contain 2.5 to $4 \mathrm{~kg}$ lead. The lead will penetrate landfills into the groundwater thereby contaminating it. It releases poisonous fumes into the air if the tube is compressed and burned (Jain, 2009; UNEP, 2010). If these electronic devices are discarded along with other household waste, the toxics pose a threat to both ecological health and critical components. Thus, when disposing or recycling e-wastes, proper management is necessary. These substances can pose major human and environmental health risks if poorly handled.

\section{Status of e-waste in India}

The amount of "e-waste" or electronic waste in India has now become a major concern. Since this everincreasing waste is potentially very complex and is also a rich source of metals such as gold, silver and copper that can be recovered and brought back into the production cycle, e-waste trade and recycling partnerships thus provide jobs for many groups of people (Baud et al., 2001). Alone in Delhi, about 25,000 employees including children are involved in crude dismantling units where 10,000-20,000 tonnes of e-waste are treated by bare hands per year (Monika and Kishore, 2010). Improper dismantling and e-waste processing renders it harmful to human health and our environment. In 2005, the total waste generated by obsolete or damaged electronic and electrical equipment was estimated at $1,46,000$ tonnes (CPCB, 2008). In 2007, India produced 380,000 tonnes of e-waste, according to the Greenpeace Report, and only $3 \%$ of this went to the facilities of approved recyclers. In 2009 it was recorded that e-waste produced was 69926 tonnes more than previous record. In 2011 the production of e-waste increased to 487515 tonnes showing rise of e-waste over the years with an alarming pace. Another study estimated that in India, companies and individual households annually obsolete approximately 1.38 million personal computers (Puckett et al., 2002), escalating the rate of e-waste generation, which is about 10 per cent, which will impact environmental health indicators annually (Mehra, 2004).

India has emerged as the world 's fifth biggest producer of electronic waste. In 2016 , India discarded about 1.85 million tonnes of e-waste, which is about 12 percent of the world's e-waste volume. Computer equipment accounts for almost $70 \%$ of e-waste, with a share of $12 \%$ from the tele-communications industry, $8 \%$ from medical equipment and $7 \%$ from annual e-waste output. Almost $75 \%$ of e-waste is generated by the government, public sector companies and private sector companies; only $16 \%$ is the contribution of individual households. Maharashtra, Andhra Pradesh, Tamil Nadu, Uttar Pradesh, West Bengal, Delhi, Karnataka, Gujarat, Madhya Pradesh, and Punjab are 
the top states, in order of the highest contribution to WEEE. The city-wise ranking of largest WEEE generators is Mumbai, Delhi, Bangalore, Chennai, Kolkata, Ahmadabad, Hyderabad, Pune, Surat, and Nagpur. Table 1 shows quantity of WEEE generation in different states in India (Wath et al., 2010).

\section{E-waste categorization and contaminants}

The composition of the e-waste is complex and very varied. There are over 1,000 compounds in e-waste that can be categorised as hazardous and non-hazardous compounds. The electrical and electronic equipment can be classified as follows (EU, 2002):

- Large household appliances (refrigerator, freezer, washing machine, cooking appliances, etc.)

- Small household appliances (vacuum cleaners, watches, grinders, etc.)

- IT and telecommunication equipment (PCs, printers, telephones, telephones, etc.)

- Consumer equipment (TV, radio, video camera, amplifiers, etc.)

- $\quad$ Lighting equipment (CFL, high intensity sodium lamp, etc.)

- Electrical and electronic tools (drills, saws, sewing machine, etc.)

- Toys, leisure, and sport equipment (computer/ video games, electric trains, etc.)

- Medical devices (with the exception of all radiotherapy equipment for implanted and contaminated products, cardiology, dialysis, nuclear medicine, etc.)

Table 1. Quantity of WEEE (Waste Electrical and Electronic Equipment) generated in Indian states (Source: Wath et al., 2010)

\begin{tabular}{llll}
\hline States & WEEE (Tonnes) & States & WEEE (Tonnes) \\
\hline Andaman and Nicobar Islands & 92.2 & Lakshadweep & 7.4 \\
Andhra Pradesh & $12,780.3$ & Madhya Pradesh & $7,800.6$ \\
Arunachal Pradesh & 131.7 & Maharashtra & $20,270.6$ \\
Assam & $2,176.7$ & Manipur & 231.7 \\
Bihar & $3,055.6$ & Meghalaya & 211.6 \\
Chandigarh & 359.7 & Mizoram & 79.6 \\
Chhattisgarh & $2,149.9$ & Nagaland & 145.1 \\
Dadra and Nagar Haveli & 29.4 & Orissa & 2937.8 \\
Daman and Diu & 40.8 & Puducherry & 284.2 \\
Delhi & $9,729.2$ & Punjab & $6,958.5$ \\
Goa & 427.4 & Rajasthan & $6,326.9$ \\
Gujarat & $8,994.3$ & Sikkim & 78.1 \\
Haryana & $4,506.9$ & Tamil Nadu & $13,486.2$ \\
Himachal Pradesh & $1,595.1$ & Tripura & 378.3 \\
Jammu and Kashmir & $1,521.5$ & Uttar Pradesh & 10381.1 \\
Jharkhand & $2,021.6$ & Uttarakhand & $1,641.1$ \\
Karnataka & $9,118.7$ & West Bengal & $10,059.4$ \\
Kerala & $6,171.8$ & Total & $146,180.7$ \\
\hline
\end{tabular}


- Monitoring and control instruments (smoke detector, heating regulators, thermostat, etc.)

- Automatic dispensers (for hot drinks, money, hot and cold bottles, etc.)

The composition of the e-waste is strongly dependent on its type; there is high variation among the 10 different categories of WEEE. e-waste contains numerous hazardous chemicals and materials like heavy metals, metalloids, halogenated hydrocarbons, and other persistent and hazardous. In addition to these toxic compounds, e-waste consists of a broad range of other material, such as glass, ceramics, plastics and rubber, rare earths, non-ferrous metals (aluminum, copper, and lead), ferrous metals (steel and iron), and precious metals (platinum group metals, gold and silver) (Lu et al., 2015). Some of the types of chemicals found in e-waste are identified in Table 2. Moreover, with technological advancement and pressure on producers from regulators and NGOs, the composition of e-wastes is shifting. Replacing CRT monitors with LCD displays will reduce the concentration of CRT lead, but mercury, indium and zinc are included in the LCD displays. Likewise, fibre optics may include fluorine, lead, yttrium, and zirconium, which may replace some copper wires. The rechargeable battery composition has also drastically changed, from nickel-cadmium to nickel metal hydrides and lithium-ion batteries (Robinson, 2009). In addition, there are concerns about the huge quantities of epoxy resins, fibreglass, PVC, thermosetting plastics, zinc, tin, copper, silicon, beryllium, carbon, iron and aluminium, and the trace amounts of germanium, tantalum, vanadium, terbium, gold, titanium,

Table 2. The nature of chemical contaminants that exist in e-waste (Source: Huang et al., 2014).

\begin{tabular}{|c|c|}
\hline Chemical & Source of these components \\
\hline Lead & $\begin{array}{l}\text { Glass of cathode ray tubes (CRT), lead-acid batteries, } \\
\text { polyvinyl chloride (PVC) cables }\end{array}$ \\
\hline Arsenic & Integrated circuit boards \\
\hline Beryllium & Connectors; Mother boards and finger clips \\
\hline Polychlorinated biphenyls (PCBs) & Electrical transformers, capacitors, PVC \\
\hline Cadmium & $\begin{array}{l}\text { Switches, solder joints, Housing, PVC cables, cathode ray } \\
\text { tubes, rechargeable Batteries }\end{array}$ \\
\hline $\begin{array}{l}\text { Polybrominated diphenyl ethers } \\
\text { (PBDEs) }\end{array}$ & Casings \\
\hline $\begin{array}{l}\text { Polychlorinated dibenzo-p-dioxins and } \\
\text { furans (PCDD/Fs) }\end{array}$ & Formation during thermal processes \\
\hline Nonylphenol (NP) & Insulators, Housing, Casing \\
\hline Triphenyl phosphate (TPP) & Casings of computer monitors \\
\hline Polychlorinated Naphthalenes (PCNs) & Capacitors, insulated wires \\
\hline Mercury (Hg) & $\begin{array}{l}\text { Batteries, flat screen electronic displays, switches, relays, } \\
\text { Housing }\end{array}$ \\
\hline Barium & CRT, Vacuum tubes \\
\hline
\end{tabular}


ruthenium, palladium, manganese, bismuth, niobium, rhodium, platinum, carbon, americium, antimony, arsenic, barium, boron, cobalt, europium, gallium, indium, lithium, manganese, nickel, palladium, ruthenium, selenium, silver, tantalum, molybdenum, thorium and yttrium (Chi et al., 2011).

\section{Effect of e-waste on water bodies}

e-waste disposal is a particular problem faced in many regions across the globe. The irrigation canals, riverbanks, wetlands and reservoirs also end up with several tonnes of e-waste material and repair residues. This is due to the disposal of recyclable materials such as acids, sludges, etc. in rivers that transport water from remote towns to meet the population's demands. For example, due to the pollution of water supplies, Guiyu, Hong Kong, a flourishing region of illegal e-waste recycling, faces acute water shortages. Landfilled computer waste creates polluted leachates that ultimately contaminate the groundwater. When plastics-containing brominates are filled with flame retardant plastic or cadmium, both polybrominated diphenyl ethers (PBDE) and cadmium can leach into the soil and groundwater. Metals and metalloids can directly diffuse into soils and groundwater from landfills as a result of natural processes or rudimentary recycling techniques via chemical or biological seepage and thus contaminate soils, agricultural crops, and drinking water resources. As rain water flows into landfills, dumpsites and open dumps, or ash and cinnamon resulting from open burning processes, hazardous substances flee into the soil and water bodies used for domestic purposes, posing risks to human health and the environment (Fent, 2004). Significant quantities of lead ions, such as the cone glass in cathode ray tubes, are dissolved from broken lead containing glass, are mixed with acid water and are a natural occurrence in landfills (Rao, 2014). In addition, the dumping of electrical waste next to ponds is very common, and metals in these scraps might reach aquatic systems with rainwater. The metals $\mathrm{Cd}, \mathrm{Cr}, \mathrm{Cu}, \mathrm{Pb}, \mathrm{Hg}$, and $\mathrm{Tl}$ and the metalloids $\mathrm{As}$ and $\mathrm{Sb}$ affect aquatic species in surface water bodies even at low concentrations. A study conducted by Greenpeace International (2008) at the Agbogbloshie scrap yard showed that some samples contained $\mathrm{Cd}, \mathrm{Hg}$ and $\mathrm{Pb}$ in quantities that are considered especially toxic to aquatic life. Amoyaw-Osei et al. (2011) also noted that the Odaw River, formerly an important fishing ground, has become dead due to extensive pollution caused by unregulated dumping and crude e-waste processing in the region.

Luo et al. (2011) found a high concentration of metals in the pond area in Guangdong province of south China. e-waste combustion locations are typically near to ponds and streams in the e-waste disposal sites, since these provide a convenient water source for metal extraction processes. Large concentrations of metals can be leached from the sites and contaminate the water and sediment of the pond. The pollution of heavy metals in sediments is an important environmental issue due to the toxicity, nondegradation and fast bioaccumulation of heavy metals (Bozkurt et al., 2000). In the sediments, common heavy metal pollutants include $\mathrm{Cr}, \mathrm{Cu}$, Ni , Cd, Zn and Pb (Monikh et al., 2013; Nithya et al., 2011). 
These sediment-fixed metals can be returned to water bodies by chemical and biological processes, and subsequently transferred to downstream rivers (Liu et al., 2009). Sediment is therefore the most critical heavy metal sink and can serve in estuary systems as a carrier and source of heavy metals. (Luo et al., 2008; Yang et al., 2012). During acid leaching processes, the acid waste and waste water produced are released into nearby streams, while solid waste is deposited on site with no or very little pollution control steps. For this reason, a thorough assessment of heavy metal contamination in sediments from acid leaching sites is critical for the environmental management and control of rivers' pollution. Considering their strong toxicity even at low concentrations, heavy metals receive special concern (Marcovecchio et al., 2007). They exist in colloidal, particulate and dissolved phases of water (Adepoju-Bello et al., 2009) with their presence in water bodies being either of natural origin, (e.g., eroded minerals in sediments, leaching of ore deposits and extruded products of volcanism) or of anthropogenic origin (i.e. solid waste disposal, industrial or household waste) (Marcovecchio et al., 2007). The Nemerow Pollution Index (PN) may represent the effect on the sediment environment of heavy metal contaminants and is commonly used to determine the overall pollution status of heavy metal sediments. (Cheng et al., 2007; Hu et al., 2013; Quan et al., 2014). PN is calculated as:

$P_{N}=\frac{\sqrt{P_{\text {imax }}^{2}+P_{\text {iave }}^{2}}}{2}$ $P_{i}=\frac{C_{i}}{C_{b}}$

where $\mathrm{Pi}$ is the pollution index for a single pollutant; $\mathrm{C}_{\mathrm{i}}$ and $\mathrm{Cb}_{\mathrm{b}}$ are the measured concentration of a heavy metal in sediment and its background value, respectively. $P_{i m a x}$ and $P_{i a v e}$ are the maximum and average pollution indices of an individual heavy metal, respectively. The degrees of heavy metal pollutions in the sediments can be classified into the following categories:

- $\quad$ Not polluted: $\mathrm{P}_{\mathrm{N}}<1.0$

- Slightly polluted: $1.0<\mathrm{P}_{\mathrm{N}}<2.0$

- $\quad$ Moderately polluted: $2.0<\mathrm{P}_{\mathrm{N}}<3.0$

- Heavily polluted: $\mathrm{P}_{\mathrm{N}}>3.0$

e-waste processing sites are usually located in fields adjacent to land used for agricultural purposes. Heavy metals released from salvaging useful materials and from the uncontrolled open burning of electronic waste could penetrate the soils where vegetables and crops are grown by contaminated irrigation water (Luo et al., 2011). Bakare (2012) investigated the potential of raw and simulated e-waste leachates to induce cytotoxicity and DNA damage in Allium cepa in a WEEE dumpsite at the Alaba, Lagos State, Nigeria. Onion bulb roots were cultivated in five concentrations: 1, 5, 10, 25 and 50 \% (v/v; 
leachate / tap water) of each leachate sample, tap water (negative control) and $0.25 \mathrm{ppm}$ (positive control) of lead nitrate. The results of the study indicate that e-waste leachate contained substances capable of inducing cytotoxicity and somatic mutations in A. cepa by inhibiting root growth and cell proliferation, and inducing genotoxicity at the chromosomal level. Alabi and Bakare (2014) conducted a research to study the cytogenotoxic effects and reproductive abnormalities induced by e-waste contaminated underground water in mice. The results showed that some of the physicochemical characteristics of the well waters were significantly higher than acceptable limits by USEPA (2009) and NESREA (2009). This is an indication of severe degradation of groundwater quality by e-waste activities and precludes its use for domestic water supply purposes. The high BOD level indicates that organics measured as BOD can cause taste and odor problems and oxygen depletion in the groundwater, thereby posing threat to those who drink it. The high concentration of TDS suggests a downward transfer of leachate into groundwater (Mor et al., 2006; Al-khaldi, 2006; Longe and Enekwechi, 2007). High concentrations of TDS decrease the palatability of water and may also cause gastrointestinal irritation in humans and laxative effects particularly upon transits (WHO, 1997).

\section{Effect of e-waste on human life}

e-waste disposals affect human health in two ways, which include: (a) food chain issues: contamination from disposal by toxic substances and primitive processes of recycling that contribute to the introduction of by-products into the food chain and thus pass to humans; and (b) direct effect of occupational exposure to hazardous substances on employees employed in primitive recycling areas. If these electronic devices are discarded along with other household waste, the toxics pose a threat to both ecological health and critical components. Breathing difficulty, respiratory discomfort, coughing, choking, pneumonitis, tremors, neuropsychiatric issues, convulsions, coma , and even death are human health hazards from e-waste (Yu et al., 2006). Table 3 shows various e-waste sources, their constituents, and impact on the health.

e-waste workers are often exposed to other dangers, such as asthma, skin diseases, eye irritations and stomach disease, leading to physical injuries and chronic conditions (Raghupathy et al., 2010). Particulate matter collected from recycling areas of e-waste can cause inflammatory reaction, oxidative stress and damage to DNA (Yang et al., 2011). Qu et al. (2007) examined the sensitivity of workers to PBDEs in China's e-waste recycling areas and found elevated levels of PBDEs with the highest BDE-209 concentration at $3436 \mathrm{ng} / \mathrm{g}$ lipid weight in the serum of the study groups. This is the highest levels of BDE-209 reported in humans so far. In the blood of children near e-waste recycling regions, high levels of $\mathrm{Pb}$ (Huo et al., 2007; Zheng et al., 2008) and Cd (Zheng et al., 2008) were found. Most of the activities related to the e-waste collection, handling, dismantling, and recycling are mainly being performed by the unorganized or informal sectors lacking the technical and infrastructural abilities and knowledge 
Table 3. E-waste substances, their sources and health impacts (Source: Kiddee et al., 2013; Rao, 2014)

\begin{tabular}{|c|c|c|}
\hline E-waste substances & Sources & Health effects \\
\hline Lead & $\begin{array}{l}\text { Soldering in printed } \\
\text { circuit boards, glass } \\
\text { panels, and computer } \\
\text { display gaskets }\end{array}$ & $\begin{array}{l}\text { Damage to central and peripheral nervous } \\
\text { systems, circulatory systems, and kidney } \\
\text { damage } \\
\text { Adverse effects on brain development of } \\
\text { children; causes damage to the circulatory } \\
\text { system and kidney }\end{array}$ \\
\hline Cadmium & $\begin{array}{l}\text { Chip resistors, } \\
\text { semi-conductorsinfrared } \\
\text { detectors, printer inks and } \\
\text { toners }\end{array}$ & $\begin{array}{l}\text { Toxic irreversible effects on human health, } \\
\text { particularly to the kidneys }\end{array}$ \\
\hline Mercury & $\begin{array}{l}\text { Batteries, backlight bulbs } \\
\text { or lamps, Relays and } \\
\text { switches, printed circuit } \\
\text { boards }\end{array}$ & $\begin{array}{l}\text { Chronic damage to the brain. } \\
\text { Respiratory and skin disorders due to } \\
\text { bioaccumulation in fishes. }\end{array}$ \\
\hline Nickel & $\begin{array}{l}\text { Batteries, computer } \\
\text { housing, cathode ray tube } \\
\text { and printed circuit boards }\end{array}$ & $\begin{array}{l}\text { Can cause allergic reaction, bronchitis and } \\
\text { reduced lung function and lung cancers }\end{array}$ \\
\hline Arsenic & $\begin{array}{l}\text { Gallium arsenide is used } \\
\text { in light emitting diodes }\end{array}$ & $\begin{array}{l}\text { Has chronic effects that cause skin disease and } \\
\text { lung cancer and impaired nerve signalling }\end{array}$ \\
\hline $\begin{array}{l}\text { Brominated flame } \\
\text { retardants }\end{array}$ & $\begin{array}{l}\text { Plastic housing for } \\
\text { electrical gadgets and } \\
\text { circuit boards. }\end{array}$ & Disrupts endocrine system functions \\
\hline Beryllium & $\begin{array}{l}\text { Motherboard, Power } \\
\text { supply boxes }\end{array}$ & $\begin{array}{l}\text { Carcinogenic (lung cancer) Inhalation of fumes } \\
\text { and dust. } \\
\text { Causes chronic beryllium disease or } \\
\text { beryllicosis. } \\
\text { Skin diseases such as warts. }\end{array}$ \\
\hline Antimony & $\begin{array}{l}\text { A melting agent in CRT } \\
\text { glass, plastic computer } \\
\text { housings and a solder } \\
\text { alloy in cabling }\end{array}$ & $\begin{array}{l}\text { Has been classified as a carcinogen. } \\
\text { Causes stomach pain, vomiting, diarrhoea and } \\
\text { stomach ulcers through inhalation }\end{array}$ \\
\hline $\begin{array}{l}\text { Plastics including } \\
\text { PVC }\end{array}$ & $\begin{array}{l}\text { Cabling and computer } \\
\text { housing }\end{array}$ & $\begin{array}{l}\text { Burning produces dioxin. It causes } \\
\text { Reproductive and developmental problems } \\
\text { Immune system damage } \\
\text { Interfere with regulatory hormones }\end{array}$ \\
\hline
\end{tabular}


about the serious implications of the e-waste handling and disposal on environment and human health. The occupational and public exposure and the bioaccumulation of toxicants that are emitted and leached from e-waste, especially if they are stored and burned in the open air, can lead to acute and chronic health disorders. These disorders include skin and eye irritation, respiratory diseases (such as coughing, choking, pneumonitis and lung cancer, tuberculosis, and asthma), mental disorders, and diseases of the central nervous system (tremors, convulsions, and cancer) (Yu et al., 2006).

\section{e-waste management}

e-waste is the fastest growing waste stream globally. A study estimated that more than 44.7 million tonnes or on average $6.1 \mathrm{~kg} /$ capita of e-waste was generated globally in 2016, an increase from $5.8 \mathrm{~kg} /$ capita in 2014. By 2021 the annual generation of e-waste is expected to increase to 52.2 million tonnes, or $6.8 \mathrm{~kg} /$ capita (Balde et al., 2017). It is estimated that $75 \%$ of electronic devices are retained due to uncertainty of how to treat them (Rao, 2014). Most of it is likely illegally dumped, but it is more likely that most of it is traded internationally and destined for "recycling" in developing countries where manual labor is cheaper and environmental and work protection standards are relaxed (Balde et al., 2017). The potential environmental disaster over e-waste flow into developing countries will be increased not only due to the huge amount of the e-waste but also by the improper treatment methods. All EU countries have a common waste management strategy and guidelines on how to decrease the environmental impact of waste. It is called the "waste management hierarchy" (Figure 3). The waste management hierarchy is as a strategy or guiding principle for manufacturers, governmental organizations, consumers and other actors in society on how to prioritize waste management approaches to decrease its environmental impacts and increase circularity.

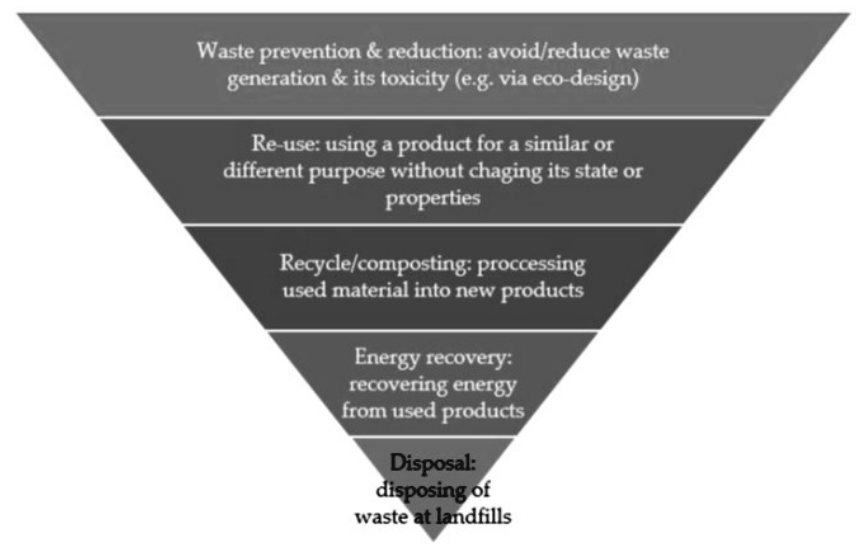

Figure 3. Waste management hierarchy (Source: Miliute-Plepiene and Youhanan, 2019) 
Although there is large amount of e-waste generation in India, there is no systematized or formal system available for handling the e-waste in a scientifically as well as environmental-friendly manner. Large amount of e-waste is being treated and dumped as a municipal solid waste only. e-waste, being rich in ferrous materials, nonferrous materials, plastic, and precious materials, has turned out as a major business opportunity for many. Although understanding and readiness to incorporate changes are growing rapidly, the major obstacles to safely and efficiently managing the e wastes remain. These include the lack of reliable data that presents a challenge for policy makers who wish to implement an e -waste management strategy and the lack of a safe e-waste recycling infrastructure.

\section{Recycling}

Many of the discarded devices contain usable parts that could be preserved and assembled to create a working device with other existing equipments. It is labour intensive to extract, inspect, analyse and then reassemble components into full working machines. For the environmentally sustainable management of e-wastes, institutional facilities, including e-waste generation, transport, care, storage, recycling and disposal, needs to be developed at national and/or regional levels. e-waste recycling is environmentally sound and requires advanced equipment and procedures, which are not only very costly but also require specialised expertise and preparation for the activity. Adequate air pollution control devices are also required for fugitive and point source emissions. The most successful and scientific method of e-waste management is currently the EXIGO recycling process (Karim et al., 2018). EXIGO is an Indian e-waste management company. The methodology for recycling involves:

- Collection: e-waste will be collected every week from various e-waste points.

- Transportation: The e-waste collected is transported in a safe and secure way using a closed container vehicle to the centralised recycling facility as per government standards.

- Segregation: Upon unloading, electronics waste segregation is done based on the size and available of components at the factory premises.

- Dismantling: After segregation of e-waste components dismantle separately.

- Recycling: After the storage of all important e-waste materials, the residual hazardous waste is recycled and disposed of by TSDF (EXIGO Recycling).

\section{Volume reduction}

Volume reduction involves certain approaches that remove a non-hazardous part of the hazardous portion of a waste. Usually, these techniques decrease the volume and therefore the expense of disposing of a waste material. The methods used to minimise the amount of waste streams can be classified into 2 general categories: source segregation and waste concentration. Wastes containing various kinds of metals should be handled independently so that they can recover the metal strength in 
the sludge. Concentration of a waste stream can increase the chance of the material being recycled or reused. Methods include filtration by gravity and vacuum, ultrafiltration, reverse osmosis, freeze vaporisation, etc. For example, a manufacturer of electronic components may use compaction equipment to reduce the volume of ray-tube waste cathode (Sepulveda et al., 2010; Environmental Health Perspectives, 2004).

\section{Sustainable product design}

Efforts need to be made to design a product that requires less amounts of hazardous substances. For example, in some modern computer designs that are flatter, lighter and more integrated, the efforts to reduce material usage are reflected. Some companies are considering centralised networks similar to the telephone system. Bio-based plastics are plastics made not even from petrochemicals, but from plant-based chemicals or plant-produced polymers. There are more frequent applications of bio-based toners, glues and inks. Solar computers still exist, but they are very costly at present. Designers must ensure that the product is designed for re-use, repair and/or upgradeability since many of the products used are non-renewable. Some tech manufactures such as Dell and Gateway lease out their goods thus ensuring they get them back to further update and lease out again.

\section{Extended producer responsibility (EPR)}

Essentially, EPR is a legislative-based indirect European Commission policy designed to ensure that market pressures are harnessed through the management of EoL EEEE to achieve environmental protection. (Hume et al., 2002). The Organization for Economic Cooperation and Development ( OECD) has described the EPR as: an environmental policy approach in which the obligation of suppliers for a commodity stretches to the post-consumer stage of the life cycle of a product, including its final disposal (OECD, 2001; Widmer et al., 2005; Walls, 2006).

Collection networks need to be developed so that e-waste is collected from the right locations so that this directly falls to the recycling unit. Collection can be accomplished through collection centres. Collection Centres may only ship wastes to dismantlers and recyclers who are getting authorization for treating, handling, refining, refurbishment, and recycling meeting environmentally sustainable management guidelines. A majority of developing countries have either prepared their EPR regulations or created them. In a successful EPR system, the true cost of waste management is internalised within the retail price by the manufacturer. The goal is to provide an opportunity to produce less toxic equipment that is inexpensive and easy to recycle. The main goals of EPR are (Langrova, 2002):

- $\quad$ waste prevention and reduction;

- $\quad$ product reuse;

- increased use of recycled materials in production; 
- $\quad$ reduced natural resource consumption;

- internalization of environmental costs into product prices; and,

- $\quad$ energy recovery when incineration is considered appropriate.

\section{Conclusion}

E-waste is a serious problem at both local and global scales. In developed countries, e-waste problems appeared initially and now eventually spread to other countries around the world. e-waste consists of several different materials, some of which contain a number of toxic substances which, if end-of-life management is not meticulously controlled, can contaminate the environment and endanger human health. Several case reports from e-waste recycling plants have reported that harmful chemicals such as heavy metals and POPs have polluted the atmosphere and continue to contaminate it. This results in considerable accumulation of hazardous substances into the ecosystem and which can adversely impact human health. The management and recycling of e-wastes has become a major global environmental problem as these could release considerable quantities of toxic heavy metals and organic compounds into the workplace environment, surrounding soils and watercourses. Heavy metals are among the major groundwater pollutants arising from manufacturing activities. Through leaching from dumpsites where processed or unprocessed e-wastes may have been stored, e-waste pollutants may enter aquatic systems. Similarly, the disposal of acid by hydrometallurgical processes used in the recovery of metals into water or soil, as well as the dissolution or settling of airborne contaminants during open fire, can often result in contamination of the aquatic environment. Therefore, there is urgent need for a concerted effort to be made by the relevant authorities to address the environmental and health hazards posed by the exposure to ewaste.

\section{References}

Adepoju-Bello, A.A., Ojomolade, O.O., Ayoola, G.A. and Coker, H.A.B. (2009). Quantitative analysis of some toxic metals in domestic water obtained from Lagos metropolis. Nigerian Journal of Pharmaceutical Research, 42(1): 57-60.

Alabi, O.A. and Bakare, A.A. (2014). Cytogenotoxic effects and reproductive abnormalities induced by e-waste contaminated underground water in mice. Cytologia, 79(3): 331-340.

Al-Khadi, S. (2006). Assessment of groundwater contamination vulnerability in the vicinity of Abqaiq landfill-A GIS Approach. King Fahd University of Petroleum and Minerals, Saudi Arabia.

Amoyaw-Osei, Y., Agyekum, O.O., Pwamang, J.A., Mueller, E., Fasko, R. and Schluep, M. (2011). Ghana e-waste country assessment. SBC e-waste Africa Project, 66: 111.

Bakare, A.A., Adeyemi, A.O., Adeyemi, A., Alabi, O.A. and Osibanjo, O. (2012). Cytogenotoxic effects of electronic waste leachate in Allium cepa. Caryologia, 65(2): 94-100.

Balde, C.P., Forti, V., Gray, V., Kuehr, R. and Stegmann, P. (2017). The Global e-waste Monitor-2017, United Nations University (UNU), International Telecommunication Union (ITU) and International Solid Waste Association (ISWA), Bonn/Geneva/Vienna. ISBN Electronic Version, pp. 978-92. 
Baud, I.S.A., Grafakos, S., Hordijk, M. and Post, J. (2001). Quality of life and alliances in solid waste management: contributions to urban sustainable development. Cities, 18(1): 3-12.

Bozkurt, S., Moreno, L. and Neretnieks, I. (2000). Long-term processes in waste deposits. Science of the Total Environment, 250(1-3): 101-121.

Cheng, J.L., Zhou, S.H.I. and Zhu, Y.W. (2007). Assessment and mapping of environmental quality in agricultural soils of Zhejiang Province, China. Journal of Environmental. Sciences, 19(1): 50-54.

Chi, X., Streicher-Porte, M., Wang, M.Y. and Reuter, M.A. (2011). Informal electronic waste recycling: a sector review with special focus on China. Waste Management, 31(4): 731-742.

CPCB (2008) Guidelines for environmentally sound management of e-waste (As approved vide MoEF letter No. 23-23/2007HSMD) Delhi: Ministry of Environment and Forests, Central Pollution Control Board, March 2008. Available from: http://www.cpcb.nic.in.

Environmental Health Perspectives (2004). vol. 112, pp. 1085-1091.

Environmental Investigation Agency (2011). System failure: The UK's harmful trade in electronic waste.

EU (2002). European Union Waste Electronic Electrical Waste (WEEE) Directive. Brussels: EU.

Fent, K. (2004). Ecotoxicological effects at contaminated sites. Toxicology, 205(3): 223-240.

Frazzoli, C., Orisakwe, O.E., Dragone, R. and Mantovani, A. (2010). Diagnostic health risk assessment of electronic waste on the general population in developing countries' scenarios. Environmental Impact Assessment Review, 30(6): 388-399.

Garg, N. and Adhana, D. (2019). E-Waste Management in India: A Study of Current Scenario. International Journal of Management, Technology and Engineering, 9.

Hicks, C., Dietmar, R. and Eugster, M. (2005). The recycling and disposal of electrical and electronic waste in China-legislative and market responses. Environmental Impact Assessment Review, 25(5): 459-471.

Hu, Y., Liu, X., Bai, J., Shih, K., Zeng, E.Y. and Cheng, H. (2013). Assessing heavy metal pollution in the surface soils of a region that had undergone three decades of intense industrialization and urbanization. Environmental Science and Pollution Research, 20(9): 6150-6159.

Huang, J., Nkrumah, P.N., Anim, D.O. and Mensah, E. (2014). e-waste disposal effects on the aquatic environment: Accra, Ghana. In Reviews of environmental contamination and toxicology, Springer, Cham. pp. 19-34.

Hume, A., Grimes, S., Jackson, T. and Boyce, J. (2002). Implementing producer responsibility: managing end-of-life consumables in an IT-service industry. In Conference Record 2002 IEEE International Symposium on Electronics and the Environment (Cat. No. 02CH37273) IEEE, pp. 144-149.

Huo, X., Peng, L., Xu, X., Zheng, L., Qiu, B., Qi, Z. and Piao, Z. (2007). Elevated blood lead levels of children in Guiyu, an electronic waste recycling town in China. Environmental Health Perspectives, 115(7): 1113-1117.

Jain, A. (2009). Development and Evaluation of Existing Policies and Regulations for e-waste in India, IEEE, International Symposium on Sustainable Systems and Technology, pp. 1-4.

Karim, S.M., Sharif, S.I., Anik, M. and Rahman, A. (2018). Negative Impact and Probable Management Policy of E-Waste in Bangladesh.

Kiddee, P., Naidu, R. and Wong, M.H. (2013). Electronic waste management approaches: An overview. Waste Management, 33 (5): 1237-1250.

Langrova, V. (2002). Comparative analysis of EPR programmes for small consumer batteries: Case study of the Netherlands, Switzerland and Sweden.

Liu, J., Li, Y., Zhang, B., Cao, J., Cao, Z. and Domagalski, J. (2009). Ecological risk of heavy metals in sediments of the Luan River source water. Ecotoxicology, 18(6): 748-758.

Longe, E.O. and Enekwechi, L.O. (2007). Investigation on potential groundwater impacts and influence of local hydrogeology on natural attenuation of leachate at a municipal landfill. International Journal of Environmental Science and Technology, 4 
(1): 133-140.

Lu, C., Zhang, L., Zhong, Y., Ren, W., Tobias, M., Mu, Z. and Xue, B. (2015). An overview of e-waste management in China. Journal of Material Cycles and Waste Management, 17(1): 1-12.

Lundstedt, S. (2011). Recycling and disposal of electronic waste health hazards and environmental impacts. Swedish Environmental Protection Agency.

Luo, C., Liu, C., Wang, Y., Liu, X., Li, F., Zhang, G. and Li, X. (2011). Heavy metal contamination in soils and vegetables near an e-waste processing site, south China. Journal of Hazardous Materials, 186(1): 481-490.

Luo, Y., Yu, X. H., Yang, Z. Y., Yuan, J. G. and Mai, B.X. (2008). Studies on heavy metal contamination by improper handling of e-waste and its environmental risk evaluation. IV. Heavy metal contamination in e-waste open burning sites. Asian Journal of Ecotoxicology, 3(1): 34-41.

Marcovecchio, J.E., Botte, S.E. and Freije, R.H. (2007). Heavy metals, major metals, trace elements. Handbook of water analysis, 2, pp. 275-311.

Mehra, H.C. (2004). PC waste leaves toxic taste, The Tribune, 22nd March.

Miliute-Plepiene, J. and Youhanan, L. (2019). e-waste and raw materials: From environmental issues to business models. IVL Swedish Environmental Research Institute.

Monika. and Kishore, J. (2010). e-waste management: as a challenge to public health in India. Indian Journal of Community Medicine, 35(3): 382.

Monikh, F.A., Safahieh, A., Savari, A. and Doraghi, A. (2013). Heavy metal concentration in sediment, benthic, benthopelagic, and pelagic fish species from Musa Estuary (Persian Gulf). Environmental Monitoring and Assessment, 185(1): 215-222.

Mor, V.I.I.I.S., Ravindra. K., Dahiya, R.P. and Chandra, A. (2006). Leachate characterization and assessment of groundwater pollution near municipal solid waste landfill site. Environmental Monitoring and Assessment, 4: 325-334.

NESREA (National Environmental Standards and Regulation Enforcement Agency) (2009). National Environmental (Sanitation and Waste Control) Regulations. Federal Republic of Nigeria Official Gazette (Abuja) 60, pp. 1057-1102

Nithya, C., Gnanalakshmi, B. and Pandian, S.K. (2011). Assessment and characterization of heavy metal resistance in Palk Bay sediment bacteria. Marine Environmental Research, 71(4): 283-294.

OECD (2001). Extended producer responsibility: a guidance manual for governments. Paris: OECD.

Otsuka, M., Itai, T., Asante, K.A., Muto, M. and Tanabe, S. (2012). Trace element contamination around the e-waste recycling site at agbogbloshie, Accra City, Ghana. Interdisciplinary Studies on Environmental Chemistry, 6: 161-167.

Puckett, J. and Smith, T. (2002). Exporting harm: the high-tech trashing of Asia The Basel Action Network. Silicon Valley Toxics Coalition, Seattle.

Puckett, J., Byster, L., Westervelt, S., Gutierrez, R., Davis, S. and Hussain, A. (2002). A report exporting harm. The High-Tech Trashing of Asia, pp. 25.

Qu, W., Bi, X., Sheng, G., Lu, S., Fu, J., Yuan, J. and Li, L. (2007). Exposure to polybrominated diphenyl ethers among workers at an electronic waste dismantling region in Guangdong, China. Environment International, 33(8): 1029-1034.

Quan, S.X., Yan, B., Lei, C., Yang, F., Li, N., Xiao, X.M. and Fu, J.M. (2014). Distribution of heavy metal pollution in sediments from an acid leaching site of e-waste. Science of the Total Environment, 499: 349-355.

Raghupathy, L., Krüger, C., Chaturvedi, A., Arora, R. and Henzler, M.P. (2010). e-waste recycling in India: Bridging the gap between the informal and formal sector. In: International Solid Waste Association, World Congress, Hamburg, Germany.

Rao, L.N. (2014). Environmental impact of uncontrolled disposal of e-wastes. International Journal of ChemTech Research, 6(2): 1343-1353.

Robinson, B.H. (2009). e-waste: an assessment of global production and environmental impacts. Science of the Total Environment, 408(2): 183-191. 
Schluep, M., Hagelüken, C., Meskers, C., Magalini, F., Wang, F., Müller, E. and Sonnemann, G. (2009). Market potential of innovative e-waste recycling technologies in developing countries. In R'09 World Congress, Davos, Switzerland.

Sepulveda, A., Schluep, M., Renaud, F.G., Streicher, M., Kuehr, R., Hagelüken, C. and Gerecke, A.C. (2010). A review of the environmental fate and effects of hazardous substances released from electrical and electronic equipments during recycling: Examples from China and India. Environmental Impact Assessment Review, 30(1): 28-41.

Streicher-Porte, M., Widmer, R., Jain, A., Baderm H.P., Scheidegger, R. and Kytzia, S. (2005). Key drivers of the e-waste recycling system: assessing and modeling e-waste processing in the informal sector in Delhi. Environmental Impact Assessment Review, 25(5): 472-91.

UNEP (2005). e-waste: the hidden side of IT equipment's manufacturing and use. Early warnings on emerging environmental threats no 5. United Nations Environment Programme.

UNEP (2010). Urgent need to prepare developing countries for surge in e-wastes. Rocketing sales of cell phones, gadgets, appliances in China, India, elsewhere forecast.

USEPA (2009). United States Environmental Protection Agency Drinking Water Contaminants. USEPA, Washington, DC.

Walls, M. (2006). Extended producer responsibility and product design: Economic theory and selected case studies.

Wath, S.B., Dutt, P.S. and Chakrabarti, T. (2011). e-waste scenario in India, its management and implications. Environmental Monitoring and Assessment, 172(1-4): 249-262.

WHO (1997). Guideline for Drinking Water Quality, 2nd ed. Health criteria and other supporting information. World Health Organization, Geneva. Vol. 2, pp. 9.

Widmer, R., Oswald-Krapf, H. and Sinha-Khetriwal, S. (2005). Global perspectives on e-waste. Environmental Impact Assessment Review, 25(5): 436-58.

Yang, F., Jin, S., Xu, Y. and Lu, Y. (2011). Comparisons of IL-8, ROS and p53 responses in human lung epithelial cells exposed to two extracts of PM2. 5 collected from an e-waste recycling area, China. Environmental Research Letters, 6(2): 024013.

Yang, Y., Chen, F., Zhang, L., Liu, J., Wu, S. and Kang, M. (2012). Comprehensive assessment of heavy metal contamination in sediment of the Pearl River Estuary and adjacent shelf. Marine Pollution Bulletin, 64(9): 1947-1955.

Yu, J., Welford, R. and Hills, P. (2006). Industry responses to EU WEEE and ROHS Directives: Perspectives from China. Corporate Social Responsibility and Environmental Management, 13(5): 286-299.

Zheng, L., Wu, K., Li, Y., Qi, Z., Han, D., Zhang, B. and Xu, X. (2008). Blood lead and cadmium levels and relevant factors among children from an e-waste recycling town in China. Environmental research, 108(1): 15-20.

*****

Cite this chapter as: Ali, S.R. and Mahrukh (2020). Impacts of e-wastes on water resources and their management. In: Advances in Environmental Pollution Management: Wastewater Impacts and Treatment Technologies, Volume 1, Eds. Kumar, V., Kamboj, N., Payum, T., Singh, J. and Kumar, P., pp. 128-144, https://doi.org/10.26832/ aesa-2020-aepm-09 